Фармакологічні дослідження біологічно активних речовин Pharmacological researches of biologically active substances

\title{
ВПЛИВ ТІОТРИАЗОЛІНУ ТА ГЕПАДИФУ НА МЕТАБОЛІЧНІ ПРОЦЕСИ У ТВАРИН 3 ГОСТРИМ ТОКСИЧНИМ ТА СУБХРОНІЧНИМ УРАЖЕННЯМ АЦЕТАМІНОФЕНОМ НА ФОНІ ДОВГОТРИВАЛОГО ЗАСТОСУВАННЯ ЕСТРОГЕНІВ ТА ПРОГЕСТИНІВ
}

\author{
CI. Б. Івануса
}

\section{Тернопільський державний медичний університет імені І. Я. Горбачевського}

\begin{abstract}
Резюме: на фоні застосування етинілестрадіолу і левоноргестрелу, які зараз широко використовують як засоби пероральної контрацепції, ацетамінофен проявляє значно вищу токсичну активність, на що вказують отримані нами результати порушень показників ендогенної інтоксикації. Значні зміни виникають навіть при семидобовому введенні ацетамінофену у вищій терапевтичній дозі. Використання тіотриазоліну та гепадифу мають нормалізуючий вплив на досліджувані показники метаболічних процесів у тварин за токсичної дії ацетамінофену на фроні тривалого застосування естрогенів і прогестинів.
\end{abstract}

Ключові слова: ацетамінофен, тіотриазолін, гепадиф, цитохромоксидаза, сукцинатдегідрогеназа, мікросомальне окиснення.

Вступ. Ацетамінофрен (парацетамол) - загальновідомий і часто вживаний препарат, який використовують замість аспірину як знеболювальний і жарознижувальний засіб. При прийманні надмірних доз препарату можливе отруєння.

Найбільш важкий ефрект при отруєнні ацетамінофреном - пошкодження печінки. Це пошкодження викликається не самим ацетамінофеном, а його метаболітами - хімічними сполуками, які утворюються при розпаді ацетамінофену. Зазвичай ці речовини нейтралізуються печінкою. Однак при дуже великій кількості метаболітів печінка не справляється з ними, результатом чого і є ії пошкодження. При тяжкому пошкодженні фрункція печінки серйозно порушується $[16,17]$.

Тіотриазолін є синтетичним кардіо- та гепатопротектором. Він попереджає пошкодження та загибель гепатоцитів; зменшує жирову інфрільтрацію та поширення некрозу печінки; активує процеси регенерації гепатоцитів та нормалізує у них білковий, вуглеводний, ліпідний та пігментний обмін; прискорює виділення жовчі та покращує їі хімічний склад. Тіотриазолін активує антиоксидантну систему та переводить вільні радикали кисню у неактивний стан, що допомагає зберегти резерви несерментативного антиоксиданту токоферолу. Препарат підвищує компенсаторну активацію анаеробного гліколізу та зменшує пригнічення процесів окиснення у циклі Кребса зі збереженням резервів АТФ $[3,9]$. Тіотриазолін також має мембраностабілізувальні властивості. Ці властивості препарату застосовують при розвитку в хворих запальних та імунологічних реакцій, оскільки проходить стабілізація мембран базофрілів, лаброцитів та еозинофрілів, що обмежує викид біогенних амінів (гістаміну, серотоніну) у кров'яне русло. Окрім цього, тіотриазолін має здатність до стабілізації мембран інших клітин, зокрема гепатоцитів, що зменшує прояви цитолітичного синдрому при ураженнях печінки [4, 11].

Створення комплексних гепатопротекторів має свої переваги, оскільки до їх складу входить кілька компонентів, які потенціюють впливи один одного, що може давати більш суттєвий есрект порівняно із прийманням монопрепарату. До найбільш відомих комплексних гепатопротекторів належить препарат Гепадиф ${ }^{\circledR}$. Терапевтична ефективність препарату Гепадис ${ }^{\circledR}$ зумовлена фрізіологічно активними речовинами метаболічної дії, що входять до складу препарату: карнітину оротату, карнітину гідрохлориду, антитоксичної фрракції печінкового екстракту, а також вітамінів групи $\mathrm{B}\left(\mathrm{B}_{2}, \mathrm{~B}_{6}, \mathrm{~B}_{12}\right)[5,10,13]$.

Зважаючи на це, ми поставили перед собою мету дослідити вплив ацетамінофену на показники енергозабезпечувального і мікросомального окиснення у тварин на фоні довготривалого застосування естрогенів та прогестинів при корекції тіотриазоліном та гепадифом.

Методи дослідження. Досліди проводили на бі-

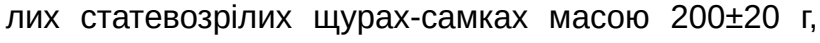
яких утримували на стандартному раціоні віварію та вільному доступі до води.

Нами було проведено 3 серії експериментів. У першій токсичне ураження викликали шляхом одноразового внутрішньошлункового введення тваринам суспензії ацетамінофену в 2 \% розчині крохмалю у дозі 1250 мг/кг маси тіла (1/2 LD50), у другій - суспензію ацетамінофену в $2 \%$ розчині крохмалю у дозі

ISSN 2312-0967. Фармацевтичний часопис. 2015. № 3 
55 мг/кг, що відповідає вищій терапевтичній дозі, вводили протягом 7 діб. Левоноргестрел у 2 \% розчині крохмалю тваринам обох серій вводили внутрішньошлунково у дозі 1,17 мг/кг маси тіла, а етинілестрадіол - в дозі 0,23 мг/кг маси тіла протягом 40 діб. Тіотриазолін тваринам вводили внутрішньочеревно в дозі 100 мг/кг. Гепадифр - внутрішньоочеревинно в дозі 8,6 мг/кг.

Піддослідних щурів поділили на 4 групи, які (крім групи I) поділяли на дві підгрупи: I - інтактні тварини (контроль); ІІа - уражені ацетамінофеном у токсичній дозі після 40-добового введення левоноргестрелу та етиніластрадіолу; ІІб тварини, яким вводили ацетамінофен у вищій терапевтичній дозі протягом 7 діб після 40-денного введення левоноргестрелу та етинілестрадіолу; IIIa - уражені ацетамінофреном у токсичній дозі після 40-добового введення левоноргестрелу, етиніластрадіолу, яким проводили корекцію тіотриазоліном; ІІІб - тварини, яким вводили ацетамінофен у вищій терапевтичній дозі протягом 7 діб після 40-денного введення левоноргестрелу та етинілестрадіолу і проводили корекцію тіотриазоліном; IVa - уражені ацетамінофеном у токсичній дозі після 40-добового введення левоноргестрелу, етиніластрадіолу, яким проводили корекцію препаратом «Гепадиф»; IVб - тварини, яким вводили ацетамінофен у вищій терапевтичній дозі протягом 7 діб після 40-денного введення левоноргестрелу та етинілестрадіолу і проводили корекцію препаратом «Гепадиф».

Тварин виводили з експерименту шляхом евтаназії за умов тіопенталового наркозу. Всі експерименти на щурах проводили відповідно до Науково-практичних рекомендацій з утриманням лабораторних тварин та роботи з ними [7].
Досліджували цільну кров, сироватку крові й гомогенат печінки. Еритроцитарний індекс інтоксикації визначали методом [14]. Визначення активності сукцинатдегідрогенази проводили згідно з методикою [2]. Визначення вмісту МСМ проводили згідно 3 методикою [15] у модифрікації [12]. Для визначення активності аланін- і аспартатамінотрансорераз (АлАТ, АсАТ) використовували метод Райтмана і Френкеля [1]. Визначення активності цитохромоксидази проводили згідно з методикою [8]. Визначення $\mathrm{N}$-деметилазної та р-гідроксилазної активностей проводили за методом [6]. Кількісні показники обробляли статистично. Достовірність різниці між порівнювальними величинами визначали за t-критерієм Стьюдента.

Результати й обговорення. При введенні тіотриазоліну встановлено зростання цитохромоксидазної та сукцинатдегідрогеназної активності в печінці щурів порівняно з ураженими тваринами. ЦО у тварин групи IIIa зросла на 93,4 \%, а групи ІІІб - на 74,2 \%. Аналогічні зміни відзначені і щодо активності сукцинатдегідрогенази. Зокрема, підвищення активності цього ензиму засріксовано у відповідних групах у 2,4 і 1,6 раза порівняно 3 тваринами, яким корекція не проводилась. Гепадиф проявляв ще більш виражену дію на процеси енергозабезпечення. У тварин групи IVa цитохромоксидазна активність перевищувала рівень уражених тварин у 2,3 раза, а у групі IVб - в 1,8 раза. Сукцинатдегідрогеназна активність змінювалась аналогічно, проте зростання було більш вираженим, ніж у випадку ЦО (табл. 1).

Використання коригувальних чинників мало позитивний вплив і на активність ферментів мікросомаль-

Таблиця 1. Цитохромоксидазна та сукцинатдегідрогеназна активність в печінці щурів за умов гострого токсичного та субхронічного ураження ацетамінофеном після 40-добового застосування етинілестрадіолу і левоноргестрелу та при корекції тіотриазоліном $(\mathrm{M} \pm \mathrm{m})$

\begin{tabular}{|c|c|c|c|c|c|c|c|c|}
\hline \multirow{3}{*}{ Показник } & \multirow{3}{*}{$\begin{array}{l}\text { Досліджу- } \\
\text { ваний } \\
\text { матеріал }\end{array}$} & \multicolumn{7}{|c|}{ Група тварин } \\
\hline & & \multirow{2}{*}{ 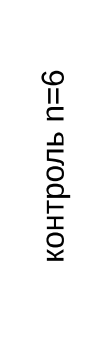 } & \multicolumn{2}{|c|}{$\begin{array}{c}\text { ацетамінофрен } \\
\text { після 40-добового } \\
\text { введення } \\
\text { левоноргестрелу та } \\
\text { етиніластрадіолу }\end{array}$} & \multicolumn{2}{|c|}{$\begin{array}{c}\text { ацетамінофен після } \\
\text { 40-добового введення } \\
\text { левоноргестрелу, } \\
\text { етиніластрадіолу, 1- та } \\
\text { 7-добового введення } \\
\text { тіотриазоліну }\end{array}$} & \multicolumn{2}{|c|}{$\begin{array}{c}\text { ацетамінофен } \\
\text { після 40-добового } \\
\text { введення } \\
\text { левоноргестрелу, } \\
\text { етиніластрадіолу і } \\
\text { корекції гепадифом }\end{array}$} \\
\hline & & & $\begin{array}{c}\text { одно- } \\
\text { разово } \\
n=6\end{array}$ & $\begin{array}{c}7 \text { діб } \\
n=6\end{array}$ & $\begin{array}{c}\text { одно- } \\
\text { разово } \\
n=6\end{array}$ & $\begin{array}{c}7 \text { діб } \\
\text { n=6 }\end{array}$ & $\begin{array}{c}\text { одно- } \\
\text { разово } \\
\mathrm{n}=6\end{array}$ & $\begin{array}{c}7 \text { діб } \\
\text { n=6 }\end{array}$ \\
\hline $\begin{array}{c}\text { Цитохром- } \\
\text { оксидаза, } \\
\text { ммоль/хв·кг }\end{array}$ & $\begin{array}{c}\text { Гомогенат } \\
\text { печінки }\end{array}$ & $\begin{array}{c}8,55 \pm \\
0,42\end{array}$ & $\begin{array}{l}3,38 \pm \\
0,40^{\star}\end{array}$ & $\begin{array}{l}4,47 \pm \\
0,52^{\star}\end{array}$ & $\begin{array}{c}6,54 \pm \\
0,58^{\star} \#\end{array}$ & $\begin{array}{l}7,79 \pm \\
0,48 \#\end{array}$ & $\begin{array}{l}7,86 \pm \\
0,33^{\star} \#\end{array}$ & $\begin{array}{l}8,22 \pm \\
0,29 \#\end{array}$ \\
\hline $\begin{array}{c}\text { Сукцинат- } \\
\text { дегідрогеназа, } \\
\text { нмоль/мг } \\
\text { білка·хв }\end{array}$ & $\begin{array}{c}\text { Гомогенат } \\
\text { печінки }\end{array}$ & $\begin{array}{c}9,29 \pm \\
0,25\end{array}$ & $\begin{array}{l}2,43 \pm \\
0,37^{\star}\end{array}$ & $\begin{array}{l}4,74 \pm \\
0,86^{\star}\end{array}$ & $\begin{array}{l}5,74 \pm \\
0,65^{\star} \#\end{array}$ & $\begin{array}{l}7,49 \pm \\
0,61^{*} \#\end{array}$ & $\begin{array}{l}6,31 \pm \\
0,42^{\star} \#\end{array}$ & $\begin{array}{l}8,57 \pm \\
0,54^{\star} \#\end{array}$ \\
\hline
\end{tabular}

Примітки.Тут і в наступних таблицях: 1) * - різниця вірогідна відносно контрольних тварин;

2) \# - різниця вірогідна відносно тварин, уражених ацетамінофеном після 40-добового введення левоноргестрелу та етиніластрадіолу.

ISSN 2312-0967. Pharmaceutical review. 2015. № 3 
Фармакологічні дослідження біологічно активних речовин Pharmacological researches of biologically active substances

ного окиснення (табл. 2). У печінці тварин групи IIIa $\mathrm{N}$-деметилазна активність підвищилась на 29 \% порівняно з ураженими тваринами, а групи IIIб - на $9 \%$. Пара-гідроксилазна активність при дії тіотриазоліну за умов одноразового введення зростала на $92 \%$, а за 7-разового - досягала величин показника у тварин контрольної групи. Позитивний вплив відмічено і при корекції препаратом «Гепадифр», однак він був дещо меншим, ніж під впливом тіотриазоліну. У групі IVa N-деметилазна активність зросла на $15 \%$, IVб на 4 \%. Пара-гідроксилазна активність змінювалась аналогічно.

Дослідження наведених вище показників показало, що ацетамінофен зумовлює розвиток в організмі експериментальних тварин низки патологічних процесів, які супроводжуються змінами (розпад тканин, зниження детоксикуючої фуункції печінки тощо). Тому наступним кроком нашої експериментальної роботи було вивчення еритроцитарного індексу інтоксикації за дії тіотриазоліну.

Еритроцитарний індекс інтоксикації при використанні тіотриазоліну в тварин з гострим ураженням ацетамінофеном після 40-добового застосування естрогенів і прогестинів знизився в 1,6 раза, а за 7-разового введення - в 1,7 раза і наближався до рівня контрольних тварин (табл. 3). За використання гепадифу Ell також достовірно знижувався і у групі IVб досягав рівня здорових тварин.

Показник $\mathrm{MCM}_{1}$ за корекції тіотриазоліном у групі IIIa становив $45 \%$ від рівня уражених тварин і наближався до показників у контрольних тварин, а у групі ІІІб не відрізнявся достовірно від рівня у контрольної групи. Аналогічне зниження виявлено і стосовно $\mathrm{MCM}_{2}$ - корекція тіотриазоліном приводила до нормалізації цього показника. Препарат «Гепадифр» проявляв аналогічну дію і до закінчення терміну спостереження показник досягав рівня контрольних тварин.

Про негативний вплив ацетамінофену на плазматичні мембрани клітин, що супроводжується структурними змінами і підвищеною проникністю їх та виходом цитозольних фрерментів, засвідчують дослідження аланін- і аспартатамінотрансорерази у плазмі крові щурів. Введення коригувальних чинників регулювало активність цитоплазматичних фрерментів.

3 наведених у таблиці 3 результатів видно, що активність АлАТ у плазмі крові експериментальних тварин, яким вводили з метою корекції тіотриазолін, істотно відрізнялася від показника в уражених тварин. У групі IIIa активність вказаного ензиму була нижча у 2,2 раза, ніж у крові уражених тварин, а у групі ІІІб - у 2,7 раза. При гострому отруєнні ацетамінофеном на фроні застосування естрогенів і прогестинів і корекції тіотриазоліном активність АсАТ була нижчою на $55 \%$ порівняно з ураженими тваринами, яким корекцію не проводили, а при введенні вищої терапевтичної дози ацетамінофену і корекції тіотриазоліном активність AсAT знизилась в 3,2 раза і наближалась до показника у крові тварин контрольної групи. Застосування гепадисру було більш ефективним. У групі IVa показник АсАТ був нижчим від рівня уражених тварин на $49 \%$, у групі IVб - на 68 \%. Аналогічні зміни спостерігались і щодо активності АлАТ - зниження, відповідно, на 62 і 68 \% порівняно з тваринами групи II (табл. 3).

Таким чином, застосування тіотриазоліну і гепадифуу в тварин 3 токсичним ураженням, викликаним введенням ацетамінофену після 40-добового застосування етинілестрадіолу і левоноргестрелу,

Таблиця 2. N-деметилазна та р-гідроксилазна активність в печінці щурів за умов гострого токсичного та субхронічного ураження ацетамінофеном після 40-добового застосування етинілестрадіолу і левоноргестрелу та при корекції тіотриазоліном (M士m)

\begin{tabular}{|c|c|c|c|c|c|c|c|c|}
\hline \multirow{3}{*}{ Показник } & \multirow{3}{*}{$\begin{array}{l}\text { Досліджу- } \\
\text { ваний } \\
\text { матеріал }\end{array}$} & \multicolumn{7}{|c|}{ Група тварин } \\
\hline & & \multirow[t]{2}{*}{ 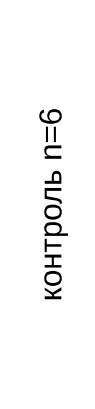 } & \multicolumn{2}{|c|}{$\begin{array}{c}\text { ацетамінофен після } \\
\text { 40-добового введення } \\
\text { левоноргестрелу та } \\
\text { етиніластрадіолу }\end{array}$} & \multicolumn{2}{|c|}{$\begin{array}{c}\text { ацетамінофен } \\
\text { після 40-добового } \\
\text { введення } \\
\text { левоноргестрелу, } \\
\text { етиніластрадіолу, } \\
\text { 1- та 7-добового } \\
\text { введення } \\
\text { тіотриазоліну } \\
\end{array}$} & \multicolumn{2}{|c|}{$\begin{array}{c}\text { ацетамінофен } \\
\text { після 40-добового } \\
\text { введення } \\
\text { левоноргестрелу, } \\
\text { етиніластрадіолу і } \\
\text { корекції гепадифром }\end{array}$} \\
\hline & & & $\begin{array}{c}\text { одно- } \\
\text { разово } \\
n=6\end{array}$ & $\begin{array}{c}7 \text { діб } \\
n=6\end{array}$ & $\begin{array}{c}\text { одно- } \\
\text { разово } \\
n=6\end{array}$ & $\begin{array}{c}7 \text { діб } \\
n=6\end{array}$ & $\begin{array}{c}\text { одно- } \\
\text { разово } \\
n=6\end{array}$ & $\begin{array}{c}7 \text { діб } \\
\text { n=6 }\end{array}$ \\
\hline $\begin{array}{c}\text { N-деметилазна } \\
\text { активність, } \\
\text { мкмоль/хв·кг }\end{array}$ & $\begin{array}{c}\text { Постміто- } \\
\text { хондріаль- } \\
\text { на фрракція } \\
\text { печінки }\end{array}$ & $\begin{array}{c}2,14 \pm \\
0,07\end{array}$ & $1,98 \pm 0,19$ & $\begin{array}{c}2,02 \pm \\
0,05\end{array}$ & $\begin{array}{l}2,55 \pm \\
0,11^{*} \#\end{array}$ & $\begin{array}{c}2,20 \pm \\
0,06\end{array}$ & $\begin{array}{c}2,27 \pm \\
0,08^{\star} \#\end{array}$ & $\begin{array}{c}2,11 \pm \\
0,05\end{array}$ \\
\hline $\begin{array}{c}\text { р-гідроксилазна } \\
\text { активність, } \\
\text { мкмоль/кг ·хв }\end{array}$ & $\begin{array}{c}\text { Постміто- } \\
\text { хондріаль- } \\
\text { на фрракція } \\
\text { печінки }\end{array}$ & $\begin{array}{c}0,32 \pm \\
0,02\end{array}$ & $\begin{array}{l}0,13 \pm \\
0,01^{*}\end{array}$ & $\begin{array}{c}0,31 \pm \\
0,03\end{array}$ & $\begin{array}{c}0,25 \pm \\
0,02^{\star} \#\end{array}$ & $\begin{array}{c}0,32 \pm \\
0,02\end{array}$ & $\begin{array}{c}0,28 \pm \\
0,02^{\star} \#\end{array}$ & $\begin{array}{c}0,31 \pm \\
0,02\end{array}$ \\
\hline
\end{tabular}

ISSN 2312-0967. Фармацевтичний часопис. 2015. № 3 
Фармакологічні дослідження біологічно активних речовин Pharmacological researches of biologically active substances

Таблиця 3. Показники ендогенної інтоксикації і стану плазматичних мембран у щурів за умов гострого токсичного та субхронічного ураження ацетамінофеном після 40-добового застосування етинілестрадіолу і левоноргестрелу та при корекції тіотриазоліном (M $\pm \mathrm{m})$

\begin{tabular}{|c|c|c|c|c|c|c|c|c|}
\hline \multirow{3}{*}{ Показник } & \multirow{3}{*}{$\begin{array}{l}\text { Досліджу- } \\
\text { ваний } \\
\text { матеріал }\end{array}$} & \multicolumn{7}{|c|}{ Група тварин } \\
\hline & & \multirow{2}{*}{ 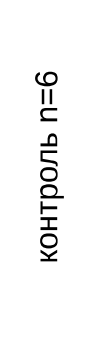 } & \multicolumn{2}{|c|}{$\begin{array}{c}\text { ацетамінофрен } \\
\text { після 40-добового } \\
\text { введення } \\
\text { левоноргестрелу та } \\
\text { етиніластрадіолу }\end{array}$} & \multicolumn{2}{|c|}{$\begin{array}{c}\text { ацетаміноден після } \\
\text { 40-добового введення } \\
\text { левоноргестрелу, } \\
\text { етиніластрадіолу, 1- та } \\
\text { 7-добового введення } \\
\text { тіотриазоліну }\end{array}$} & \multicolumn{2}{|c|}{$\begin{array}{c}\text { ацетамінофен } \\
\text { після 40-добового } \\
\text { введення } \\
\text { левоноргестре-лу, } \\
\text { етиніластрадіо-лу і } \\
\text { корекції гепадифом }\end{array}$} \\
\hline & & & $\begin{array}{c}\text { одно- } \\
\text { разово } \\
\mathrm{n}=6\end{array}$ & $\begin{array}{l}7 \text { діб } \\
\mathrm{n}=6\end{array}$ & $\begin{array}{c}\text { одно- } \\
\text { разово } \\
\mathrm{n}=6\end{array}$ & $\begin{array}{c}7 \text { діб } \\
\mathrm{n}=6\end{array}$ & $\begin{array}{c}\text { одно- } \\
\text { разово } \\
\mathrm{n}=6\end{array}$ & $\begin{array}{l}7 \text { діб } \\
\text { n=6 }\end{array}$ \\
\hline $\begin{array}{c}\text { Еритро- } \\
\text { цитарний індекс } \\
\text { інтоксикації, \% }\end{array}$ & Кров & $\begin{array}{c}32,3 \pm \\
2,73\end{array}$ & $\begin{array}{c}84,65 \pm \\
3,64^{*}\end{array}$ & $\begin{array}{c}65,42 \pm \\
2,46^{*}\end{array}$ & $\begin{array}{l}52,14 \pm \\
2,80^{\star} \#\end{array}$ & $\begin{array}{c}38,22 \pm \\
2,31 \#\end{array}$ & $\begin{array}{l}50,22 \pm \\
1,54^{\star} \#\end{array}$ & $\begin{array}{l}35,16 \pm \\
1,27 \#\end{array}$ \\
\hline $\begin{array}{c}\text { Молекули } \\
\text { середньої } \\
\text { маси }_{1} \text {, ум.од. } \\
\text { екст. } \\
\end{array}$ & $\begin{array}{c}\text { Плазма } \\
\text { крові }\end{array}$ & $\begin{array}{c}0,34 \pm \\
0,02\end{array}$ & $0,94 \pm 0,07^{*}$ & $\begin{array}{l}0,67 \pm \\
0,04^{\star}\end{array}$ & $\begin{array}{l}0,42 \pm \\
0,04 \#\end{array}$ & $\begin{array}{l}0,38 \pm \\
0,04 \#\end{array}$ & $\begin{array}{l}0,40 \pm \\
0,03 \#\end{array}$ & $\begin{array}{l}0,36 \pm \\
0,02 \#\end{array}$ \\
\hline $\begin{array}{c}\text { Молекули } \\
\text { середньої } \\
\text { маси }_{2}, \text { ум.од. } \\
\text { екст. } \\
\end{array}$ & $\begin{array}{c}\text { Плазма } \\
\text { крові }\end{array}$ & $\begin{array}{c}0,11 \pm \\
0,01\end{array}$ & $0,43 \pm 0,02^{*}$ & $\begin{array}{l}0,28 \pm \\
0,002^{\star}\end{array}$ & $\begin{array}{l}0,21 \pm \\
0,02^{\star} \#\end{array}$ & $\begin{array}{l}0,15 \pm \\
0,01^{*} \#\end{array}$ & $\begin{array}{l}0,18 \pm \\
0,02^{\star} \#\end{array}$ & $\begin{array}{l}0,13 \pm \\
0,01 \#\end{array}$ \\
\hline $\begin{array}{c}\text { АсАТ ммоль/л } \\
\text { г год } \\
\end{array}$ & $\begin{array}{c}\text { Плазма } \\
\text { крові }\end{array}$ & $\begin{array}{c}0,36 \pm \\
0,09 \\
\end{array}$ & $1,92 \pm 0,38^{*}$ & $\begin{array}{l}1,36 \pm \\
0,21^{*}\end{array}$ & $\begin{array}{l}0,86 \pm \\
0,15^{\star} \#\end{array}$ & $\begin{array}{l}0,42 \pm \\
0,12 \#\end{array}$ & $\begin{array}{l}0,75 \pm \\
0,09^{\star} \#\end{array}$ & $\begin{array}{l}0,44 \pm \\
0,07 \#\end{array}$ \\
\hline $\begin{array}{c}\text { АлАТ ммоль/л } \\
\text { год } \\
\end{array}$ & $\begin{array}{c}\text { Плазма } \\
\text { крові }\end{array}$ & $\begin{array}{c}0,58 \pm \\
0,11\end{array}$ & $3,18 \pm 0,65^{*}$ & $\begin{array}{l}2,16 \pm \\
0,55^{\star}\end{array}$ & $\begin{array}{l}1,46 \pm \\
0,28^{\star} \#\end{array}$ & $\begin{array}{l}0,81 \pm \\
0,05 \#\end{array}$ & $\begin{array}{l}1,22 \pm \\
0,11^{\star} \#\end{array}$ & $\begin{array}{l}0,69 \pm \\
0,06 \#\end{array}$ \\
\hline
\end{tabular}

виявлено позитивний вплив на стабілізацію плазматичних мембран клітин, що проявлялось вірогідним зниженням активності цитозольних ферментів АлАТ та AcAT. Ці дані, як і показник EII, очевидно можуть слугувати опосередкованим критерієм значного покращання стану плазматичних мембран гепатоцитів.

\section{Література}

1. Горячковский А. М. Справочное пособие по клинической биохимии / А. М. Горячковский. - Одесса : ОКФа, 1994. - 415 c.

2. Ещенко Н. Д. Методы биохимических исследований / Н. Д. Ещенко, Т. Г. Вольский. - Л. : Из-во Ленинград. унта, 1982. - С. 210-212.

3. Івануса І. Б. Вплив тіотриазоліну на стан печінки при їі ураженні ацетамінофеном на фоні тривалого введення естрогенів та прогестинів / І. Б. Івануса // XIV Міжнародний медичний конгрес студентів і молодих вчених, 13-15 квітня 2010 року : матеріали конгресу. Тернопіль, 2010. - С. 229.

4. Івануса І. Б. Вплив тіотриазоліну на деякі показники антиоксидантної системи, вільнорадикального окиснення та ендогенної інтоксикації у щурів з токсичним ураженням ацетамінофеном на тлі тривалого введення естрогенів і прогестинів / І. Б. Івануса // Медична хімія. 2011. - № 3. - С. 75-80.

5. Івануса І. Б. Особливості показників вільнорадикального окиснення і антиоксидантної системи у тварин за
Висновок. Підсумовуючи отримані результати можна вказати на те, що досліджувані нами показники окиснювальних процесів і ендогенної інтоксикації зазнавали позитивного впливу коригувальних чинників, що відображалося у зменшенні показників ендогенної інтоксикації й частковій нормалізації процесів енергозабезпечувального та мікросомального окиснення.

умов гострого токсичного та субхронічного ураження ацетамінофеном на тлі довготривалого застосування естрогенів та прогестинів при корекції тіотриазоліном та гепадифом / І. Б. Івануса // Фармацевтичний часопис. 2015. - № 2 (34). - С. 101-107.

6. Карузина И. И. Выделение микросомальной фрракции печени и характеристика ее окислительных систем / И. И. Карузина, А. И. Арчаков // Современные методы в биохимии ; под ред. В. Н. Ореховича. - М. : Медицина, 1977. - C. 49-62.

7. Кожем'якін Ю. М. Науково-практичні рекомендації 3 утримання лабораторних тварин та роботи 3 ними / Ю. М. Кожем'якін, О. С. Хромов, М. А. Філоненко. - К. : Авіцена, 2002. - 156 с.

8. Кривченкова Р. С. Метод определения активности цитохромоксидазы в суспензии митохондрий / Р. С. Кривченкова // Современные методы в биохимии; под. ред. В. Н. Ореховича. - М. : Медицина, 1977. - С. 47-49.

9. Минушкин О. Н. Некоторые гепатопротекторы в лечении заболеваний печени / О. Н. Минушкин //

ISSN 2312-0967. Pharmaceutical review. 2015. № 3 
Фармакологічні дослідження біологічно активних речовин Pharmacological researches of biologically active substances

Лечащий врач. - 2002. - № 6. - С. 55-58.

10. Дискриминантный и корреляционный анализ влияния препарата гепадиср на активность процессов фриброзирования при дифффузных заболеваниях печени / Л. К. Пальгова, Н. Б. Касенова, О. В. Рейман [и др.] // Проблемы гастроэнтерологии. - 2007. - № 4. - С. 191-192.

11. Применение гепатопротективной терапии при лечении хронических заболеваний и поражений печени : методические рекомендации / под общей ред. А. Л. Ракова. - М., 2006. - 22 с.

12. Роль среднемолекулярных пептидов крови в развитии кардиодепрессии при термических ожогах / Р. И. Лифшшиц, Б. М. Вальдман, И. А. Волчегорский, А. С. Лужевский // Бюлл. эксперим. биол. и медицины. 1986. - Т. 101, № 3. - С. 280-282.

13. Садыков К. Б. Опыт применения гепатопротектора
Гепадифр при хронических вирусных гепатитах В и С / К. Б. Садыков // Медицина. - 2003. - № 5. - С. 46-50. 14. Способ диагностики эндогенной интоксикации / А. А. Тогайбаев, А. В. Кургузкин, И. В. Рикун, Р. М. Карибжанова // Лаб. дело. - 1988. - № 9. - С. 22-24.

15. Среднемолекулярные пептиды спинномозговой жидкости при гнойных менингитах / В. В. Оськина, К. И. Чекалина, Н. И. Габриэлян, В. В. Малеев // Лаб. дело. - 1987. - № 2. - С. 23-25.

16. Acetaminophen Toxicity in an Urban County Hospital / F. V. Schiodt, F. A. Rochling, D. L. Casey, W. M. Lee / New England Journal of Medicine. - 1997. - Vol. 337, № 16. P. 1112-1117.

17. Zimmerman H. J. Acetaminophen (paracetamol) hepatotoxicity with regular intake of alcohol: analysis of instances of therapeutic misadventure / H. J. Zimmerman // Hepatology. - 1995. - № 22. - P. 767.

\title{
ВЛИЯНИЕ ТИОТРИАЗОЛИНА И ГЕПАДИФА НА МЕТАБОЛИЧЕСКИЕ ПРОЦЕССЫ У ЖИВОТНЫХ С ОСТРЫМ ТОКСИЧЕСКИМ И СУБХРОНИЧЕСКИМ ПОРАЖЕНИЕМ АЦЕТАМИНОФЕНОМ НА ФОНЕ ДЛИТЕЛЬНОГО ПРИМЕНЕНИЯ ЭСТРОГЕНОВ И ПРОГЕСТИНОВ
}

\section{И. Б. Ивануса}

\author{
Тернопольский государственный медицинский университет имени И. Я. Горбачевского
}

Резюме: на фоне применения этинилэстрадиола и левоноргестрела, которые сейчас широко используют в качестве средств пероральной контрацепции, ацетаминофен проявляет значительно более высокую токсическую активность, на что указывают полученные нами результаты нарушений показателей эндогенной интоксикации. Значительные изменения возникают даже при семидневном введении ацетаминосена в высшей терапевтической дозе. Использование тиотриазолина и гепадифа нормализует исследуемые показатели метаболических процессов у животных при токсическом действии ацетаминофена на фроне длительного применения эстрогенов и прогестинов.

Ключевые слова: ацетаминофен, тиотриазолин, гепадиф, цитохромоксидаза, сукцинатдегидрогеназа, микросомальное окисления.

\section{INFLUENCE THIOTRIAZOLINE AND HEPADIF ON METABOLIC PROCESSES OF ANIMALS WITH ACUTE TOXIC AND SUBCHRONIC LESIONS BY ACETAMINOPHEN WITH PROLONGED USAGE OF ESTROGEN AND PROGESTIN}

\section{B. Ivanusa}

\section{Ternopil State Medical University by I. Ya. Horbachevsky}

Summary: ethinylestradiol and levonorgestrel is widely used as oral contraceptives. Acetaminophen has more toxic activity at prolonged their usage, as indicated by our obtained results of endogenous intoxication changing. Significant changes are occurred even at seven-day acetaminophen administration in high therapeutic dose. Usage thiotriazoline and hepadif normalizes investigated parameters of metabolic processes of animals with acute toxic and subchronic lesions by acetaminophen with prolonged usage of estrogen and progestin.

Key words: acetaminophen, thiotriazoline, hepadif, cytochrome oxidase, succinate dehydrogenase, microsomal oxidation. 